The conducted analysis of scientific literature has shown that highly qualified athletes who find themselves in professional sports are part of the so-called "risk group" of workers who are most prone to burnout. It is substantiated that "emotional burnout in sport» is a very complicated psycho-physiological reaction. On the one hand, it is a mechanism of psychological protection against stress factors of professional activity. On the other hand, the syndrome of emotional burnout refers to professional deformations of the person, which are treated as a specific form of professional deformation of an individual. It is proved that emotional burnout in sport should be considered in the analytical section of the individual characteristics of the athlete and the internal aspects of their professional activities.

Key words: emotional burnout in sports, stress factors, professional activity, athlete.

УДК 159.923.5

Ж. П. ВІРНА, К. О. ПОВАР

\title{
СТАТЕВОРОЛЬОВА ІДЕНТИФІКАЦІЯ ЯК ЧИННИК ПСИХОЛОГІЧНОГО БЛАГОПОЛУЧЧЯ СІМЕЙНОГО ПОДРУЖЖЯ
}

Стаття присвячена вивченню статеворольової ідентифікації в межах визначення психологічного благополуччя сімейного подружжя. Теоретичний аналіз проблеми вміщує розгляд особливостей статеворольової ідентифікаиії особистості та специффіку переживання психологічного благополуччя сімейного подружжя. Емпірична експлікачія проблеми розкрита через визначення зв'язку статеворольової ідентифікації та психологічного благополуччя сімейного подружжя. На основі розробленої емпіричної програми вивчення проблеми з'ясовано зміст прояву маскулінності, фремінності $i$ андрогенності у благополучних (конструктивних) $i$ неблагополучних (деструктивних) сімейних парах.

Ключові слова: статеворольова ідентифікачія, психологічне благополуччя, сімейне подружжся, маскуліннсть, фемінність, андрогінність, благополучні (конструктивні) сімейні пари, неблагополучні (деструктивні) сімейні пари.

Статья посвящена изучению полоролевой идентификащии в пределах определения психологического благополучия семейных пар. Теоретический анализ проблемы вмещает рассмотрение особенностей полоролевой идентификации личности и специфику переживания психологического благополучия семейных пар. Эмпирическая экспликация проблемы раскрыта через определение связи полоролевой идентификации и психологического благополучия семейных пар. На основе разработанной эмпирической программы изучения проблемы выяснено содержание проявления маскулинности, феминности и андрогенности в благополучных (конструктивных) и неблагополучных (деструктивных) семейных парах.

Ключевые слова: полоролевая идентификачия, психологическое благополучие, семейные nары, маскулинность, феминность, андрогенность, благополучные (конструктивные) семейные пары, неблагополучные (деструктивные) семейныле пары.

Постановка проблеми. Аналіз психологічного благополуччя сімейного подружжя набирає усе більше обертів у межах соціально-психологічних досліджень. На фоні різких соціально-економічних змін в суспільстві саме підтримка позитивного, сприятливого клімату в сімейному середовищі є запорукою не лише сімейного, а й загального життєвого комфорту особистості. Також у межах психологічних досліджень сучасної сім’ї і сімейних відносин, усе гостріше заявляють про себе такі феномени порушення партнерської комунікації як страх психологічної інтимності, синдром «емоційного холоду» i «токсичної любові», міжособистісна залежність / контрзалежність тощо, які суттєво порушують процеси становлення психологічного благополуччя особистості, яке, в свою чергу, є інтегральною характеристикою їі якості життя. 
3 огляду на аналіз останніх досліджень і публікацій з проблеми варто відзначити доробки наукової школи О. Кочаряна, у роботах якого визначено, що симптомокомплекс маскулінності/ фемінінності $є$ стрижневим регулюючим утворенням, що $є$ базовою структурою, котра визначає соціальне й психічне благополуччя людини. Статеворольові чинники пов'язані зі сферами соматичного (О. Кочарян), психологічного (А. Коцар, Є. Фролова, Н. Ярова та ін.), соціального (Н. Терещенко), сексуально-партнерського (Н. Смахтіна) благополуччя тощо. Ідеї генетичної психології (С. Максименко), положення гуманістичної та позитивної психології (А. Маслоу, Г. Олпорт, К. Роджерс, М. Селігман, Е. Фромм), центральні конструкти евдемоністичної парадигми в розумінні психологічного благополуччя (К. Ріфф) та статеворольовий і гендерний підходи в психології (Т. Говорун), склали базову основу в аналізі досліджуваної проблеми.

Формулювання цілей статті. Наукове повідомлення спрямоване на теоретикоемпіричне обгрунтування статеворольових чинників психологічного благополуччя сімейного подружжя.

Виклад основного матеріалу дослідження. Теоретичний екскурс у заявлену проблему потребує передусім розгляду ідентичності, яка $є$ визначальним фактором для формування особистості, набуття нею тієї сукупності соціальних ролей, що є прийнятними в оточуючому соціумі, полегшує та робить можливим нормальне функціонування суб'єкта ідентичності у суспільстві, дозволяючи йому вважати себе належним до певних соціальних груп із подальшим прийняттям правил поведінки, норм моралі, цілей та цінностей даних угруповань. Коли йдеться про статеворольову ідентичність, то зазначається її типовий прояв у сфері належності суб'єкта до певної статі. 3 біологічної точки зору, стать є визначальною стосовно ролі суб'єкта при репродукції та здебільшого зводиться до систематизації фізіологічних та морфологічних особливостей, які $\epsilon$ необхідними для статевого розмноження. 3 іншого боку, поняття статевої належності та статі $є$ позначенням для особистого соціального статусу індивіда незалежно від статі. Більшість авторів зазначають, що сучасним дітям надається значно менш чітке, проте більш гнучке уявлення про жіночність та мужність. Проте не варто відкидати ті фактори, що є визначальними для формування статевої ролі дівчинки чи хлопчика [1].

Процесу формування статево-рольових стереотипів та установок характерний тісний зв'язок із психосексуальним розвитком особистості. Згідно із теорією об'єктних взаємин В. Файербраєна та Дж. Мастерсона, виникнення моделі ідентифікації пов'язане із внутрішніми образами матері та батька, які, у свою чергу, $є$ визначальними щодо характеристики особливостей его-об'єктних зв'язків із матір'ю (оральна залежність, симбіотична прихильність, нарцистична досконалість тощо). Образ же батька $\epsilon$ першоосновою для подальших інтерперсональних взаємин суб'єкта та маскулінності. Маскулінність передбачає такі типи поведінки, що є очікуваними від чоловічої статі, та спрямовані на підтримку цільових орієнтацій. Також така поведінка відображає незатребуваність стосовно міжособистісних контактів. Фемінна роль передбачає у своєму складі ті види активності, що орієнтуються на заохочення взаємно-корисних якостей при здійсненні міжособистісних взаємодій. Тому саме ця орієнтована на образ матері. Ідентифікація згідно із цією моделлю проходить завдяки інтеріоризації батьківських образів 3 обов'язковим врахуванням характерологічних особливостей включно із характером взаємин між дітьми та батьками (із обов'язковим розподілом на «хороші» та «погані» частини). Ідентифікація із батьками набуває внутрішньо суперечливого, неоднозначного характеру, при цьому «хороша» частина спілкування спрямовується на задоволення лібідинозних бажань суб'єкта (і це свідчить про ii фемінний характер), тоді як «погана» частина має загрозливий характер через покарання, критику (що дозволяє схарактеризувати іiї як маскулінну). У когнітивно-генетичній теорії К. Томпсон та Л. Кольберг зазначають, що модель ідентифікації базується на когнітивних процесах: 1) усвідомлення дитиною існування двох статей; 2) включення дитиною себе до однієї із двох статей; 3) керування власною поведінкою, що базується на самовизначенні. Суть цієї моделі полягає в активному характері відображення в дитячій свідомості їі власного досвіду, що здійснюється завдяки засвоєнню 
когнітивних структур основних заданих статевих установок когнітивної сфери. Модель ідентифікації Ч. Халверсона та Г. Мартіна будується на статево-рольових стереотипах, котрі існують у схематичному вигляді, та які є допоміжним засобом у організації та структуризації наявної інформації. Згідно із цією моделлю, існує дві схеми, що пов'язані із процесом засвоєнням статевої ролі: 1) схема, до складу якої входить загальна та необхідна дитині інформація, що спрямовується на категоризацію ролі та поведінки жінки або чоловіка; 2) схема власної статі, котра виступає в якості більш деталізованої та специфічної версії попередньої схеми, включаючи до свого складу при цьому інформацію про форми поведінки, речі та особистісні властивості, що $\epsilon$ характерними для власної статі [4]. Згідно із аналітичною теорією К. Юнга, виникнення моделей ідентифікації відбувається на грунті архетипів Анімуса та Аніме. При цьому, зазначає науковець, співвідношення жіночністьчоловічність слугує показником незрілості-зрілості особистості. Для досягнення зрілості суб'єкт повинен звільнитись від наявної первинної фемінної ідентичності, при чому чоловікові слід подолати первинну фемінність, тоді як жінка повинна подолати материнський комплекс [6].

У ході проведення аналізу нами відмічено, що суб'єкт може стикатися 3 рядом проблем при проходженні ідентифікації, що також пов'язано із особливостями наявних у соціумі правил, норм, поведінкових та статевих стереотипів. Також фемінність та маскулінність передбачають ряд очікуваних від суб'єкта ліній поведінки та вчинків, котрі вважаються відповідними та прийнятними для даної статі у даному суспільстві. Отже, процес статево-рольової ідентифікації - невід'ємна складова кожної особистості та обов'язкова умова для нормального життя та взаємодії із соціумом та іншими людьми. При цьому, логічним є передбачення, що специфіка статеворольової ідентифікації визначає зміст психологічного благополуччя особистості. Психологічне благополуччя, як комплексне поняття, вміщує до свого складу такі елементи: 1) прийняття самого себе (тобто позитивне оцінювання власної особи та власного життя); 2) взаємини з іншими позитивного характеру; 3) автономність, тобто вміння слідувати власним переконанням; 4) наявність цілей, котрі надають життю сенсу та спрямованості; 5) компетентність, що проявляється в контролі над оточуючим середовищем, вмінні здійснювати ефективне керівництво власним життям); 6) особистісний ріст, котрий розцінюється як неперервний розвиток та самореалізація [2]. Також П. Фесенко наголошує, що свідомість життя та психологічне благополуччя значимо корелюють із смисложиттєвими орієнтаціями особистості та рівнем ії свідомості життя [5]. Ж. Вірна вважає, що психологічне благополуччя $\epsilon$ аспектом відображення його аксіологічних ознак, які є невід'ємним компонентом руху людини до іï самоактуалізації, розкриття власного потенціалу, побудови перспективи розвитку, i, як наслідок винайдення конструктивної стратегії життя [3]. У науковій позиції психофізіологічного збереження функцій Р. Райана та Е. Десі, зазначається, що очевидною $\epsilon$ наявність зв'язку між психологічним благополуччям та фізичним здоров'ям [7]. А в теорії позитивного психологічного функціонування особистості К. Ріфф проведено узагальнення й виокремлення основних компонентів психологічного благополуччя: позитивні взаємини 3 оточуючими, самоприйняття, автономність, керування оточуючим середовищем, особистісний ріст, життєва ціль [8].

На основі проведеного дослідження є усі підстави для ствердження, що психологічне благополуччя - це комплексне явище, існування якого забезпечується сумісним функціонуванням кількох елементів на декількох ієрархічних рівнях. Психологічне благополуччя $\epsilon$ свідченням нормального та успішного існування та функціонування особистості в соціумі, і сімейному середовищі зокрема. Тому логіка побудови емпіричної програми стосується вивчення статеворольових чинників психологічного благополуччя сімейного подружжя. Для реалізації поставленої мети використано такі психодіагностичні методики: тест-опитувальник задоволеності шлюбом (В. Столін, Т. Романова, Г. Бутенко), опитувальник «Конструктивно-деструктивна сім'я» (КДС) (Е. Ейдеміллер, В. Юстицькис), опитувальник «Вимірювання установок в подружній парі» (Ю. Альошина), методика «Хто Я» (М. Кун, Т. Макпартленд), методика «Маскулінності-фемінності» (С. Бем). Вибірку 
дослідження склали: 35 сімейних пар з періодом перебування у шлюбі він 1 до до 47 років. Обсяг вибірки становить 70 осіб.

У результаті опрацювання емпіричних даних за тест-опитувальником «Задоволеності шлюбом» (В. Столін, Т. Романова, Г. Бутенко) та опитувальником «Конструктивнодеструктивна сім'я» (КДС), діагностовані були поділені на дві групи: група 1 - благополучні (конструктивні) пари (22 пари); група 2 - неблагополучні (деструктивні) пари (12 пар). Також при обробці результатів було враховано період перебування партнерів у шлюбі, в результаті чого усі випробувані пари були поділені на 3 підгрупи: 1 - сімейний стаж від 1 до 12 років; 2 - від 13 до 20 років; 3 - сімейний стаж більше ніж 21 рік. Встановлено, що серед пар, які проживають в шлюбі від 1 до 12 років: $67 \%$ - становлять благополучні та конструктивні сімейні подружжя; 33 \% - становлять неблагополучні та деструктивні сімейні подружжя. Подружні пари, сімейний стаж яких становить від 13 до 20 років: 60\% становлять благополучні та конструктивні сімейні подружжями; $40 \%$ - становлять неблагополучні, деструктивні сімейні подружжя. Пари з сімейним стажем більшим ніж 21 рік: $60 \%$ - становлять благополучні та конструктивні сімейні подружжями; $40 \%$ - становлять неблагополучні, деструктивні сімейні подружжя.

Згідно результатів методики «Вимірювання установок в подружній парі» (Ю. Альошина) виявлено, що серед благополучних, конструктивних сімей переважає позитивне ставлення до людей (100\%), орієнтація на задоволення $(85 \%)$, значима роль дітей в сім’ї (95\%), орієнтація на спільну діяльність (75\%), негативне ставлення до розлучення (95\%), орієнтація на кохання романтичного типу $(70 \%)$, значуща сексуальна сфера в подружньому житті (80\%), не $\epsilon$ забороненою тема сексуальних стосунків (95\%), егалітарна організація сімейних стосунків $(65 \%)$, бережливе ставлення до грошей $(85 \%)$. А серед неблагополучних, деструктивних сімей переважає позитивне ставлення до людей (85\%), орієнтація на обов'язок (70\%), значима роль дітей в сім'ї (85\%), орієнтація на роздільну діяльність (75\%), нейтральне ставлення до розлучення (65\%), орієнтація на традиційну (не романтичну) любов (65\%), значуща сексуальна сфера в подружньому житті $(70 \%)$, не $\epsilon$ забороненою тема сексуальних стосунків (85\%), патріархальна організація сімейних стосунків (55\%), заощадливе ставлення до грошей (90\%).

При обробці результатів методики «Хто Я» (М. Кун, Т. Макпартленд), основна увага була приділена відповідям, які стосувалися того як партнери почувають себе в сім'ї, як бачать себе в ній, як ставляться до виконуваної сімейної та подружньої ролі та які емоції при цьому переживають. Опрацьовані відповіді були диференційовані за трьома групами емоційно позитивного забарвлення, емоційно нейтрального забарвлення та емоційно негативного забарвлення. В результаті виявлено, що серед благополучних сімей переважаючим є емоційно позитивне забарвлення ставлення партнерів до своєї сімейної ролі, виявлена незначна кількість пар 3 емоційно нейтральним забарвленням та не виявлено жодної з емоційно негативним забарвленням. Серед неблагополучних сімей переважаючим $\epsilon$ емоційно нейтральне забарвлення ставлення партнерів до виконуваної сімейної ролі, незначна кількість пар 3 переважанням емоційно позитивного забарвлення, але також не виявлено пар з переважанням емоційно негативного забарвлення.

При порівнянні діагностованих груп за методикою «Маскулінності-фемінності» (С. Бем) виявлено, що серед жінок з благополучних сімей, у $59 \%$ відмічено домінування фемінності, у 41\% - домінування андрогінності. Серед чоловіків з благополучних сімей, у 55\% переважають ознаки андрогінності, у 36\% - переважає маскулінність та у 9\% переважання фемінності. Серед жінок $з$ неблагополучних сімей, у 46\% осіб переважає маскулінність, у $31 \%$ респондентів - андрогінність та у $23 \%$ опитаних - фемінність. Серед чоловіків 3 неблагополучних сімей у $38 \%$ осіб переважає маскулінність, у $31 \%$ андрогінність та у $31 \%$ опитаних - фемінність.

У результаті застосування коефіцієнту кореляції Пірсона, вдалося виявити статистично значущий зв'язок між багатьма показниками. Зокрема, серед благополучних пар, які перебувають у шлюбі від 1 до 12 років, існує зв'язок між показниками стажу та рівнем психологічного благополуччя сімейного подружжя в чоловіків $(\mathrm{r}=-0,658$ при $\mathrm{p}<0,05)$. Тобто 3 
чоловічої точки зору, чим довше пара перебуває в шлюбі, тим меншим $є$ рівень психологічного благополуччя в сім'ї. У неблагополучних пар, які перебувають у шлюбі від 1 до 12 років виявлено кореляційни зв'язок між показниками: маскулінності чоловіків та фемінності жінок ( $\mathrm{r}=0,878$ при $\mathrm{p}<0,05)$; фемінності жінок та рівнем психологічного благополуччя сімейного подружжя в чоловіків ( $\mathrm{r}=0,959$ при $\mathrm{p}<0,01)$; психологічного благополуччя сімейного подружжя чоловіків та жінок $(\mathrm{r}=0,879$ при $\mathrm{p}<0,05)$. Таким чином, чим вищим $\epsilon$ рівень фемінності дружини, тим більшим $\epsilon$ рівень психологічного благополуччя в сім'ї чоловіка і навпаки, а також чим вищим $\epsilon$ рівень психологічного благополуччя в сім'ї чоловіка, тим вищим він буде у дружини і навпаки.

Серед благополучних пар, які перебувають у шлюбі від 13 до 20 років визначено кореляційний зв'язок між показниками: стажу та фемінності жінок $(\mathrm{r}=0,917$ при $\mathrm{p}<0,01)$, тобто, чим довше жінка перебуває у шлюбі, тим вищими будуть ii показники рівня фемінності; показниками психологічного благополуччя сімейного подружжя чоловіків та жінок ( $\mathrm{r}=0,817$ при $\mathrm{p}<0,05)$, що свідчить про те, що чим вищим є рівень психологічного благополуччя в сім'ї чоловіка, тим вищим він буде у дружини. Серед неблагополучних пар, які перебувають у шлюбі від 13 до 20 років встановлено кореляційний зв'язок між показниками: психологічного благополуччя сімейного подружжя чоловіків та жінок ( $\mathrm{r}=-0,951$ при $\mathrm{p}<0,05)$. Тобто високий рівень психологічного благополуччя в сім'ї чоловіка зумовлює менший показник у дружини.

Серед благополучних пар, які перебувають у шлюбі 21 рік і більше встановлено кореляційний зв'язок між показниками: стажу та рівня психологічного благополуччя сімейного подружжя в чоловіків ( $\mathrm{r}=0,899$ при $\mathrm{p}<0,05)$, що свідчить про те, що чим довше пара перебуває в шлюбі, тим вищим є рівень психологічного благополуччя в сім’ї з чоловічої точки зору; стажу та рівня психологічного благополуччя сімейного подружжя в жінок $(\mathrm{r}=0,920$ при $\mathrm{p}<0,01)$; маскулінності чоловіків та фемінності жінок $(\mathrm{r}=0,841$ при $\mathrm{p}<0,05)$; психологічного благополуччя сімейного подружжя чоловіків та жінок $(\mathrm{r}=0,954$ при $\mathrm{p}<0,01)$, що свідчить про те, що чим вищим є рівень психологічного благополуччя в сім'ї чоловіка, тим вищим він буде у дружини і навпаки.

Серед неблагополучних, деструктивних пар, які перебувають у шлюбі 21 рік і більше визначено кореляційний зв'язок між показниками психологічного благополуччя сімейного подружжя чоловіків та жінок ( $\mathrm{r}=-0,952$ при $\mathrm{p}<0,05)$, що свідчить про те, що чим вищим $\epsilon$ рівень психологічного благополуччя в сім’ї чоловіка, тим меншим він буде у дружини і навпаки.

Висновки 3 даного дослідження та перспективи подалыших розвідок. Отримані результати проведеного дослідження показали, що статеворольова ідентифікація є потужним фактором переживання психологічного благополуччя сімейного подружжя. Емпірично доведено, що відмінності прояву фемінності у жінок та андрогінності у чоловіків у благополучних сімейних парах та домінування прояву маскулінності у жінок і чоловіків у неблагополучних сімейних парах, зумовлюють зміст переживання психологічного благополуччя сімейного подружжя: у благополучних сімейних парах переважає позитивне ставлення до людей, орієнтація на задоволення, значима роль дітей в сім'ї, орієнтація на спільну діяльність, негативне ставлення до розлучення, орієнтація на кохання романтичного типу, значуща сексуальна сфера в подружньому житті, егалітарна організація сімейних стосунків, бережливе ставлення до грошей; у неблагополучних сімейних парах переважає позитивне ставлення до людей, орієнтація на обов'язок, орієнтація на роздільну діяльність, нейтральне ставлення до розлучення, орієнтація на традиційну (неромантичну) любов, патріархальна організація сімейних стосунків.

Перспективи подальших розробок вбачаємо в конкретизації показників психологічного благополуччя досліджуваних, які уможливлять удосконалення теоретикометодологічних конструктів вивчення цього феномену та прикладних аспектів дослідження його аксіологічної гармонізації. 


\section{Список використаних джерел}

1. Анзорг Л. Дети и семейный конфликт: книга для учителя / Л. Анзорг. - М. : Просвещение, 1988. - 93 с.

2. Ветрова В. В. Уроки психологического здоровья / В. В. Ветрова. - М. : Академия, 2000. - 192 c.

3. Вірна Ж. П. Аксіологія якості життя особистості / Ж. П. Вірна // Психологія особистості. - 2013. - № 1 (4). - С. 104-112.

4. Кочарян А. С. Личность и половая роль / А.С. Кочарян; пер. с англ. М. Н. Георгиевой. - Харків : Основа, 1996. - 127 с.

5. Фесенко П. П. Осмысленность жизни и психологическое благополучие личности : автореф. дисс. ... канд. псих. наук / П. П. Фесенко. - М. : 2005. - 24 с.

6. Юнг К. Конфликты детской души / К. Юнг. - М. : Наука, 1995. - 336 с.

7. Deci E. L. The «what» and «why» of goal pursuits: Human needs and the self determination of behavior / E. L. Deci, R. M. Ryan // Psychological Inquiry. - 2000. - Vol. 11. P. 87-90.

8. Ryff C. D. The Structure of Psychological Well-Being / C. D. Ryff, C. L. M. Keyes // Journal of Personality and Social Psychology. - 1995. - Vol. 69. - P. 719-727.

\section{References}

1. Anzorg L. Deti i semeynyiy konflikt: kniga dlya uchitelya. / L. Anzorg. - M. : Prosveschenie, 1988. - $93 \mathrm{~s}$.

2. Vetrova V. V. Uroki psihologicheskogo zdorovya / V. V. Vetrova. - M. : Akademiya, 2000. $-192 \mathrm{~s}$.

3. Virna Zh. P. AksiologIya yakosti zhittya osobistosti / Zh. P. Virna // Psihologiya osobistosti. - 2013. - № 1 (4). - S. 104-112.

4. Kocharyan A. S. Lichnost i polovaya rol / A.S. Kocharyan; per. s angl. M. N. Georgievoy. - HarkIv : Osnova, 1996. - 127 s.

5. Fesenko P. P. Osmyislennost zhizni i psihologicheskoe blagopoluchie lichnosti : avtoref. diss. ... kand. psih. nauk / P. P. Fesenko. - M. : 2005. - 24 s.

6. Yung K. Konfliktyi detskoy dushi / K. Yung. - M. : Nauka, 1995. - 336 s.

7. Deci E. L. The «what» and «why» of goal pursuits: Human needs and the self determination of behavior / E. L. Deci, R. M. Ryan // Psychological Inquiry. - 2000. - Vol. 11. R. 87-90.

8. Ryff C. D. The Structure of Psychological Well-Being / C. D. Ryff, C. L. M. Keyes // Journal of Personality and Social Psychology. - 1995. - Vol. 69. - P. 719-727.

\section{Zh. Virna, K. O. Povar. SEX-ROLE IDENTIFICATION AS THE FACTOR OF FAMILY COUPLE PSYCHOLOGICAL WELFARE.}

The article is devoted to the study of sex-role identification within the definition of family couple psychological well-being. Theoretical analysis of the problem includes the consideration of the peculiarities of individual sex-role identification and the specifics of the feeling of family couple psychological well-being. The empirical explication of the problem, revealed through the definition of the connection between family couple sex-role identification and psychological well-being. On the basis of the developed empirical program of the problem studying, the content of manifestation of masculinity, femininity and androgyny in prosperous (constructive) and disadvantaged (destructive) family couples are determined. The domination of femininity manifestation between women and androgyny between men in successful couples as well as the domination of masculinity between women and men in disadvantaged couples are revealed. According to the parameters of the family experience of prosperous and disadvantaged family couples, the psychological strengthening of these sex-role identifications of the marital spouse has been recorded, which makes it possible to state that sex-role identification is one of the main factors of the psychological well-being of the family couples, which determines the level of overall satisfaction with the marriage. 
Key words: sex-role identification, psychological welfare, family couple, masculinity, femininity, androgyny, prosperous (constructive) family couples, disadvantaged (destructive) family couples.

\section{УДК 159.9.072-026.15}

\section{О. I. АРТЕМОВА, І. А. ДРУЖИНІНА}

\section{КРЕАТИВНІСТЬ ЯК ЗАПОРУКА ПРОФЕСІОНАЛІЗМУ ВЕДУЧОГО ТРЕНІНГОВИХ ГРУП}

Зміст статті полягає у дослідженні особливостей розвитку креативності як професійної та особистісної якості майбутнього практичного психолога у прочесі проведення тренінгових занять та навчання ведучих тренінгових груп.

Підготовка практичних психологів до різних аспектів професійної діяльності передбачає використання широкого спектра форм та методів навчання. Одним зі способів подолання репродуктивного підходу в підготовичі практичних психологів $є$ підвищення активності суб'єктів навчального прочесу та впровадження активно-творчих форм $i$ методів навчання майбутніх спеціалістів. Яскравою особливістю активно-творчих методів $\epsilon$ проведення різного роду тренінгів $i$ ефективне навчання ведучих тренінгових груп, навиками яких повинен володіти кожен психолог. Ефективність тренінгу залежить від особистості тренера, від його уміння створити в групі атмосферу емпатії, щүирості, саморозкриття, теплі взаємини між членами групи $i$ ведучим. Креативність $i \epsilon$ тією особистісною якістю, яка дозволяе ведучому піклуватися про створення максимально сприятливих умов для самопізнання, самоактуалізації та розвитку учасників групи, щэо $i$ забезпечує ефективність тренінгової роботи.

Проблеми професійної підготовки майбутніх практичних психологів до роботи 3 різними категоріями клієнтів розкриваються саме через розкриття креативного потенціалу ведучих тренінгових груп. Ведучий повинен мати великий запас терпіння, оскільки впродовж роботи він може зустріти зовсім різних людей, зіткнутися з різними проблемами, для розв'язання яких потрібні витримка, вольовий самоконтроль, гнучке і дивергентне мислення. Сам тренінг - найефективніша технологія навчання конкретним навичкам $i$ умінням, а креативність - риса особистості, запорука професіоналізму.

Ключові слова: креативність, риса, професіоналізм, тренінг, тренінгові технологї, ведучий тренінгових груп.

Содержание статьи заключается в исследовании особенностей развития креативности как профессионального и личностного качества будущего психолога в процессе проведения тренинговых занятий и обучения ведущих тренинговых групп.

Подготовка практических психологов к различным аспектам профессиональной деятельности предполагает использование широкого спектра форм и методов обучения. Одним из способов преодоления репродуктивного подхода в подготовке практических психологов является повышение активности субъектов учебного процесса и внедрение активно-творческих форм и методов обучения будущих специалистов. Яркой особенностью активно-творческих методов является проведение различного рода тренингов $u$ эффективное обучение ведущих тренинговых групп, навыками которых должен обладать каждый психолог. Эффективность тренинга зависит от личности тренера, от его умения создать в группе атмосферу эмпатии, искренности, самораскрытия, теплые отномения между членами группы и ведущим. Креативность и является тем личностным качеством, которая позволяет ведущему заботиться о создании максимально благоприятньх условий для самопознания, самоактуализачии и развития участников группь, и обеспечивает эффективность тренинговой работыл.

Проблемы профессиональной подготовки будущих практических психологов к работе с различными категориями клиентов раскрываются именно через раскрытие креативного

Випуск 10, 2018. Збірник наукових праць РДГУ 